\title{
Production system and competitive power of Chinese enterprises
}

\section{-A case study on TCL King color TV}

(C) Higher Education Press and Springer-Verlag 2007

\begin{abstract}
Taking TCL's color TV production system as an example, this paper discusses the formation process and causes of the production system of China's manufacturing industry. The work flow and operation mode of the fast production line in TCL color TV manufacturing base (Huizhou) are studied in detail. The results show that the forming of TCL color TV production system's competitive power within such a short time is credited to three reasons: advantage of backwardness and creative imitation, fast duplication capacity, and a marketized performance appraisal system.
\end{abstract}

Keywords competitive advantage, fast duplication, evolution capability

摘要 采用与国际接轨的、规范性的案例研究方法, 以TCL彩电生产系统为案例 研究对象, 探讨中国制造业生产系统的形成过程与原因。通过详细考察TCL彩电 生产基地 (惠州) 快速生产线的流程与运作模式, 对快速生产线上管理与绩效考核 及其演变过程进行了详细地调查研究。TCL彩电生产系统能在短期内形成竞争 能力主要有 3 个方面原因: 享受后发利益与创造性模仿、形成快速复制的经营能 力、市场化的绩效考核。

关键词 竞争优势, 快速复制, 进化能力

Translated and revised from Guanli Shijie 管理世界 (Management World), 2004, (12): 109119

OUYANG Taohua, ZHANG Chuyu ( $₫)$

School of Business, Renmin University of China, Beijing 100872, China

E-mail: chuyeeee@yahoo.com.cn; chuyee@public3.bta.net.cn

LI Jiahong, MAO Yunshi, LU Weihang

School of Business, Sun Yat-sen University, Guangzhou 510275, China 


\section{Research purpose and method}

\subsection{Purpose}

By studying the color TV production system of TCL Group Corporation (hereinafter referred to as TCL Group or TCL), we attempt to probe into the formation process of production system in China's manufacturing industry and its competitive capacity. Since the reform and opening up over 20 years ago, China has witnessed the emergence of many excellent manufacturing enterprises, as represented by TCL, Haier and Lenovo. When competing with enterprises from Europe, the USA, Japan and South Korea in the domestic market, these outstanding national enterprises have gained certain comparative advantages. They have also actively participated in the trend of globalization. Among these domestic enterprises, TCL is regarded as a representative of a new generation of Chinese manufacturing enterprises. Entering "TCL's competitive capacity" as keywords to search for related articles, one may find as many as hundreds of papers studying on this topic. Some of these papers expatiated the formation of TCL's competitiveness from the perspectives of TCL's internationalization and merger and acquisition strategies; other papers described the competitive advantages of TCL's marketing strategies from the aspects of TCL's establishment of its own sales network, brand building and product design conforming to market demand; still other papers depicted TCL's organizational innovation achievements from the viewpoints of TCL's organizational structure innovation and its peopleoriented human resource strategy. Taken together, most of extant literature has expounded the high-speed growth and competitive advantages of TCL from the aspects of diversification, internationalization, organizational innovation and marketing strategy, etc. which are quite helpful to our study on the competitive capacity of TCL.

Most of the above research, however, lacked field survey and elaborate case study and failed to discuss the competitive capacity of China's manufacturing industry from the angle of product development and production system. As we know, production system is the foundation of competitiveness. An enterprise's products would be competitive at home and abroad only when its production system has gained competitive advantages. In China, color TV industry is generally recognized as an industry with the most intense price competitions and highest degree of marketization. TCL Group entered the color TV industry in 1992 and produced only 1,500 color TV sets in the same year through original equipment manufacturer (OEM). Only eleven years later, TCL's annual production capacity reached more than 10 million sets of color TV per year. TCL's fast production line was able to assemble a color TV within 12 seconds on average, a world-class takt time in TV manufacturing industry at that time. In 2002, the 
selling price of 21" color TV dropped to less than 1,000 RMB yuan in China. Many color TV manufacturers had to sell products below cost in order to keep the market share and reduce stocks. In such an intense competition, though TCL 21" color TV priced only a bit more than 800 yuan, it still earned about 8 yuan per set. It is the high-performance color TV production system that supports TCL's high-speed growth and becomes the basis and source of TCL's competitiveness. Why could TCL build the world-class color TV production scale and a high-performance production system within a mere twelve years? How do China's manufacturing enterprises understand and cultivate competitiveness of their own? This paper is going to answer the above questions.

\subsection{Method}

Through adopting the standard case study method, we attempt to probe into the formation process and causes of the production system in China's manufacturing industry by means of case studying TCL's color TV production system. Generally speaking, to explicate existing management systems (e.g. product development and manufacturing system) in an enterprise, we need to describe from two aspects: first, what the system is and why it is established (description of the system establishment); second, what are the reasons for the system's stable existence (description of the system existence). TCL started its color TV business 12 years ago. Why could TCL build world-class manufacturing capacity in such a short time? What is the rationality of the phenomenon of TCL? To answer the above questions, authors of this paper made special trips to Huizhou City, Guangdong Province four times to study TCL's color TV production system and collect raw materials for our case study.

Existing studies on the acquisition of enterprise's competitive advantage can be divided into two schools: endogenetic determinism and exogenous determinism. The former mainly focuses on enterprise's internal resources capability and argues that the long-term competitive advantages of an enterprise mainly come from the valuable, scare, inimitable and unsubstitutable resources or assets (Barney, 1991). The latter mainly studies the outside industrial environment (Nelson and Winter, 1982) and deems external environment a selective force of an enterprise's survival. We believe that external environment works only through internal elements, thus we adopt the endogenetic determinism perspective in this paper. Starting from analyzing the production manufacturing system, we will endeavor to find out TCL's endogenous and inimitable competitive capacity in this article.

Among the scholars specializing in the study on manufacturing enterprises from the perspective of product development and production system, Professor Fujimoto from Japan is by far the most representative one, who, through a 
follow-up study on Toyota for as long as twelve years, published his famous monograph The Evolution of A Manufacturing System at Toyota (Takahiro, 1999). In the book, Professor Fujimoto argued that the competitive advantages of Toyota find expression in its unique production mode and continuously endogenetized evolution capability. According to Fujimoto's analysis framework, the competitive powers of an enterprise fall into three levels, namely static capability, improvement capability and evolution capability (as shown in Table 1). The static capability represents enterprise competitiveness in the stable state. For instance, the production system with which the enterprise can achieve expected production efficiency and product quality within a certain time range. The improvement capability refers to a continuous enhancement of enterprise comparativeness (such as production efficiency and product quality) through constantly improvement of the product development and production system. Besides, an enterprise is able to copy such capabilities to other production systems. The evolution capability is on the third level, representing an advancement of enterprise's capability from imitation to innovation. In addition, since the evolution capability is inimitable to other enterprises. It belongs to the core competitiveness of an enterprise. Using the analytical framework of Professor Fujimoto, this paper mainly discusses the competitive power of the TCL color TV production system.

\section{Production system of TCL King color TV}

\subsection{Evolution of TCL color TV production system}

Since its foundation in 1980, TCL has maintained a high-speed growth for more than 20 years and has developed into a huge enterprise group. Its business domain ranges from household electric appliances, IT, communication technology to electric engineering and its major products include color TV, computer, mobile telephone, electric product, ice refrigerator and air conditioner, etc. According to a TCL posting, the number of employees in 2002 was 37,358 (including 4,207 technical personnel) and the sales income was 30.98 billion yuan. Below, we present a brief review of TCL's development over the past years.

In 1980, Huiyang Electronic Industry Company was founded in Huizhou Prefecture, Guangdong Province ${ }^{1}$, which was finally developed into TCL Group after 15 years.

\footnotetext{
${ }^{1}$ Huiyang Electronic Industry Company changed its name to Huiyang Electronic Industry General Company in 1984. In 1988, the latter was renamed again as Huizhou Electronic Industry Company.
} 
Table 1 Three levels of product development and productive capacity

\begin{tabular}{|c|c|c|c|}
\hline Level & Basic properties & Influenced objects & Interpretation in this paper \\
\hline Static capability & Static reproduction & $\begin{array}{l}\text { Competitiveness } \\
\text { achievement indices } \\
\text { in the stable state }\end{array}$ & $\begin{array}{l}\text { Under normal conditions, } \\
\text { enterprises' product } \\
\text { development and } \\
\text { manufacturing system } \\
\text { can process product } \\
\text { manufacturing } \\
\text { information repeatedly, } \\
\text { accurately and } \\
\text { effectively }\end{array}$ \\
\hline $\begin{array}{l}\text { Improvement } \\
\text { capability }\end{array}$ & $\begin{array}{l}\text { Dynamic } \\
\text { reproduction }\end{array}$ & $\begin{array}{l}\text { Competitiveness } \\
\text { improvement indices } \\
\text { and responsiveness } \\
\text { to changes }\end{array}$ & $\begin{array}{l}\text { It can not only solve } \\
\text { problems quickly } \\
\text { and efficiently, } \\
\text { but also handle } \\
\text { static information }\end{array}$ \\
\hline $\begin{array}{l}\text { Evolution } \\
\text { capability }\end{array}$ & $\begin{array}{l}\text { Innovation and } \\
\text { inimitableness }\end{array}$ & $\begin{array}{l}\text { Quick competitiveness } \\
\text { building and } \\
\text { effectiveness }\end{array}$ & $\begin{array}{l}\text { Having the genes } \\
\text { for creation capability } \\
\text { building, the capability } \\
\text { is also evolving } \\
\text { constantly and thus } \\
\text { it is inimitable to } \\
\text { other enterprises }\end{array}$ \\
\hline
\end{tabular}

Source: The evolution of a manufacturing system at Toyota, p. 17.

In 1996, China's color TV market was quite prosperous. But in the spring of that year, a company called Luks Industrial (Group) Limited (hereinafter referred to as Luks Group) was ready to sell out its color TV manufacturing base in Shekou District, Shenzhen owing to the company's poor realty business performance $^{2}$. TCL seized this opportunity and purchased the Shekou Plant from Luks Group and established Shenzhen TCL King Electronics Co., Ltd. All color TVs manufactured by this plant started to use the brand name of "TCL King". On June 19, 1996, TCL Group started to construct its own color TV production base in Zhongkai Development Zone, Huizhou City. The new base covers a land of 92,900 square meters and has seven productions lines (including one fast production line). From project programming, plant design, workshop construction

\footnotetext{
${ }^{2}$ Luks Industrial (Group) Co., Ltd. was founded by Mr. Lu Qingtian in 1975 and its gross assets have reached US $\$ 120$ million by 1996. Its main business included color TV manufacturing and realty business. Luks Group started to make investment in the Chinese mainland from 1979 and built Shekou Color TV Production Base in Shenzhen in 1982. After a development for more than a dozen of years, the annual output of color TV sets topped one million and it took the lead in passing ISO9002 certification in the Chinese mainland thanks to its advanced scientific research facilities and strong technical strength and was the first domestic TV manufacturer that got the qualification to export color TV sets to the USA.
} 
to production line assembling, this base was constructed in accordance with the advanced level in the 1990s. With the completion of this new color TV manufacturing base in January, 1998, TCL King Electric Appliances (Huizhou) Co., Ltd. was founded. At present, this base in Huizhou boasts a manufacturing capacity of 2,000 TV sets per shift and 3 million TV sets per year. The products manufactured cover a wide variety of $14^{\prime \prime}$ to $51^{\prime \prime}$ TVs ranging from analog TV, digital TV, projector TV, Rear-projection TV to color monitor.

Starting from 1997, TCL Group has adopted a way of quickly expanding its color TV production scale and capability through merger and joint investment. In August, 1997, TCL Group jointly invested with Henan Anyang CPT Glass Bulb Group and established Henan TCL-Meile Electronics Co., Ltd. to manufacture TCL King color TV sets and electronic tuners. By coping TCL's management mode and manufacturing technologies, the new company's annual TV production capability boosted from the original 260,000 sets per year to $1,500,000$ sets per year.

In September, 1999, Irico Group, TCL Group, Baotou Trust and Huhhot municipal government signed the "Irico TV Set Plant Reorganization Agreement" in Beijing. Iroco's plant building, production units, land and 900 employees were transferred to TCL Group for free to set up Inner Mongolia TCL King Electric Appliances Co., Ltd. After the merger, the productive capacity of TCL Inner Mongolia company was greatly improved. For example, the number of color TV sets produced in the plant from September to the end of 1999 was 121,000. The next year, the number quadrupled to 518,000 sets per year. The number reached 820,000 in 2001.

In December, 2000, TCL Industrial Holdings (Hong Kong) Ltd. and Dianyi Assets Management Co., Ltd. in Wuxi City jointly founded TCL Digital Science and Technology (Wuxi) Co., Ltd. to produce high-tech products such as digital TV, PDA, PC, AV, STB, network access equipment, etc.

By 2001, TCL's color TV production center had five color TV manufacturing bases nationwide and an annual color TV production capability of more than 7 millions sets.

In August, 2002, TCL Group and Great Wall Cyber (Hong Kong) Company co-invested 10 million Hong Kong dollars and founded a joint venture (named as Global International Co., Ltd. temporarily) to pave TCL's way for the international market and to provide outsourcing service to transnational tycoons.

In September, 2002, TCL Group purchased Schneider Electric Co., Ltd., a household electric appliance enterprise in Germany, and obtained Schneider's R\&D labs and technical personnel. Schneider Electric had three color TV production lines, an annual color TV production capability of about 1 million, and a complete network of sales channels in Europe.

Through the above merger and joint venture, TCL proliferated its annual color TV production capability to more than 10 million sets within less than ten years: 
the brand name of "TCL King" was first used in 1995; the first production line and manufacturing base (TCL King Electric Appliance Huizhou Co., Ltd.) were put into production in 1998; with the merger of the two color TV enterprises in Henan Province and Inner Mongolia and the duplication of TCL's management mode to these merged enterprises, TCL's annual color TV production capability rocketed. How was the production mode of TCL King color TV formed and what are the "genes" behind these duplications? We may get helpful inspirations through analyzing the production base of TCL King Electric Appliance (Huizhou) Co., Ltd.

\subsection{Production system of TCL King color TV}

As mentioned-above, TCL group's business domain covers four major industries, namely household electric appliances, IT, communication technology and electric engineering. The household electric appliance division is the biggest division in TCL, including TCL electronics sales Co., Ltd., TV business unit, TCL white household electric appliances business unit, TCL air conditioner business unit (as shown in Appendix 1, TCL organization chart). Among them, the TV business unit is the biggest business unit in household electric appliances division. The above-mentioned TCL King color TV production center belongs to this unit (as shown in Appendix 2, organization chart of TV business unit). From 1996 to 2003, by means of merger, acquisition and oversea investment, TCL King color TV production center set up five domestic manufacturing bases ${ }^{3}$ and three international bases (TCL-Schneider Co., TCL Russia Co., TCL Vietnam Co., $\mathrm{Ltd}^{4}$ ) (as shown in Fig. 1). Except for TV teletrons and core modules, all other components parts for color TV assembly are produced or processed internally.

\subsubsection{Production system in Huizhou plant}

TCL King Electronics (Huizhou) Co., Ltd. (Below referred to as King Huizhou for short), is located at Zhongkai Development Zone, Huizhou City. It is a subsidiary company of TCL color TV production center and the biggest color TV

\footnotetext{
${ }^{3}$ In September, 2002, TCL group signed an agreement with Great Wall Electronics Group. Accordingly, TCL started to reform the former manufacturing base of former Great Wall Electronics Group in Zhongkai Development Zone. The reformed manufacturing base produced color TV for TCL in OEM way. After the reform, the Huizhou base's daily production capacity reached more than 7,500 sets and became the second biggest production base for TCL King in Huizhou City.

${ }^{4}$ TCL Vietnam Co., Ltd. was founded in November, 1999 and was specially designed to produce color television, VCD, DVD and other household electric appliances. The plant has an annual production capacity of 300,000 color TV, 400,000 VCD and DVD. There are more than 300 Vietnamese workers and six Chinese technical experts in this plant (including about 50 technicians).
} 


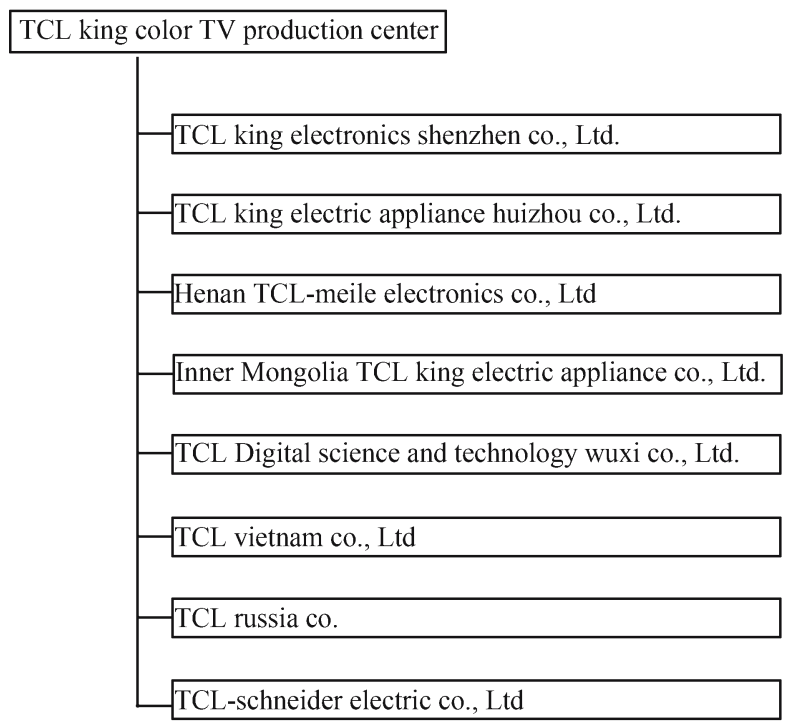

Fig. 1 TCL King color TV production center Source: TCL internal information.

production and trial production base of TCL (as shown in Fig. 2). The production base of King Huizhou has more than 1,500 employees (including 180 technical and managerial personnel). These employees have an average age of 22 and a majority of them have high school education level or above. King Huizhou has two CTV (finished color TV assembly) workshops, one for domestic sales and the other for oversee sales. The average production capacity of CTV workshop for oversea sales is about 2,000 sets per shift and the annual production capacity about 3.6 million sets.

There are over 700 employees working in the CTV workshop production lines, including 30 senior managerial personnel with ranks higher than team leaders.

CTV workshop for domestic sale has six assembly production lines, namely CTV.A, CTV.B, CTV.C, CTV.D, CTV.E, CTV.F, one trial production line, one louderspeaker sub-line and one finished products storehouse for inspection. The workshop can produce simultaneously different size of color TV sets ranging from $21^{\prime \prime}$ to $38^{\prime \prime}$. In particular, as the fastest color TV production line in the world, CTV.F can assembly one complete set of color TV in every 12 seconds, representing the highest management level of TCL color TV production system.

\subsubsection{CTV.F fast production line}

CTV.F refers to the fast production line for complete color TV set assembly in CTV Workshop for Domestic Sales. It has a daily color TV production 


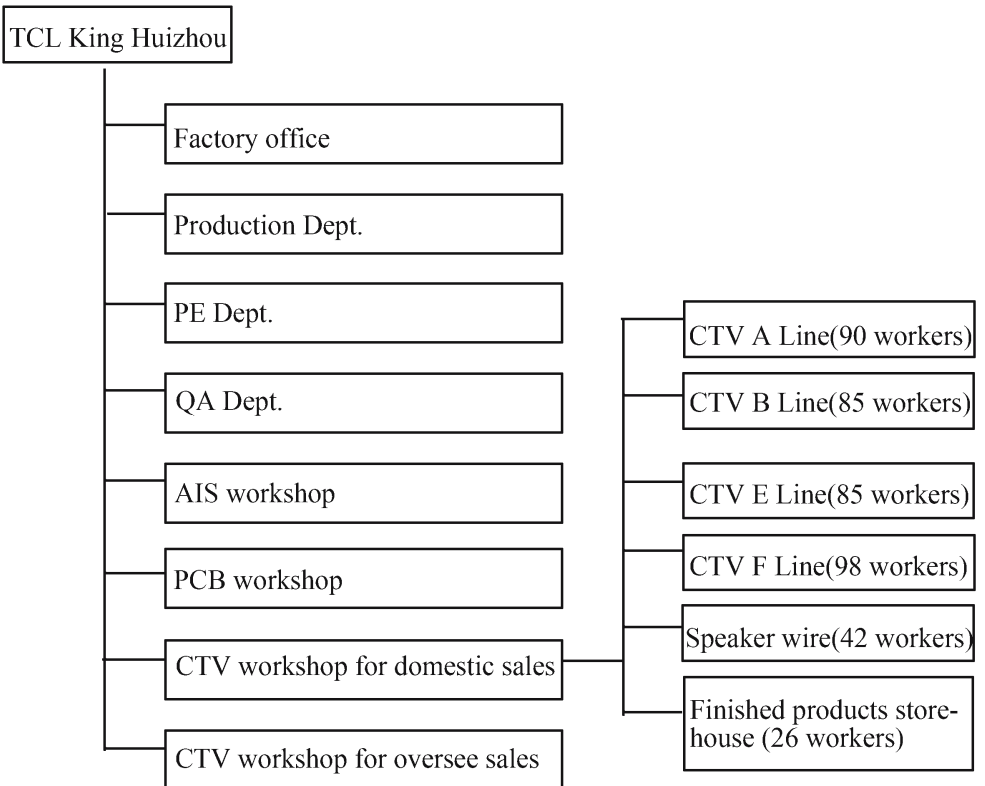

Fig. 2 TCL King Huizhou organization chart

QA stands for quality assurance; AIS for automatic inserting system; CTV for color TV; PCB for printed circuit board; and PE for production engineering

Source: TCL internal information.

capacity of about 2,500 sets, one set in 12 seconds on average. As a world-class production line, CTV.F represents the shortest takt time of TCL color TV production system. Takt time here stands for overall efficiency of a color TV production system. The shorter the takt time is, the more finished products are produced within the same amount of time. But the continuous reduce of takt time cannot be obtained unless relevant factors in a production system, such as personnel, production engineering and component parts have been optimized and coordinated in the first place. A cut in takt time denotes that the production system is in a state of controlled and continuous optimization. Generally speaking, a complete color TV set assembly process consists of four teams, namely assembly team, processing team, debugging \& inspection team (the combination of color TV debugging team and quality inspection team), and packing team. Specifically, assembly team and debugging \& inspection team are in charge of most of the jobs in the production line. Assembly team is responsible for putting together color TV sets. Processing team sees to all kinds of auxiliary jobs. And packing team is responsible for the work at the final step on the main production line. 


\subsubsection{Process and key positions of the fast production line}

About 98 workers (there is a fluctuation of $5 \%$ to $10 \%$ in the number of workers in accordance with the production difficulty level of different color TV models) work in the fast production line. Production process is shown in Fig. 3, where steps for four teams are separately marked with dotted lines. In the fast production line, color TV teletrons pass through assembly team and then go into the aging-test line (color TV aging-test step). Processing team is in charge of making color TV cabinets. After that, the finished and assembled color TV sets go into the step of debugging and inspection before leaving the factory. As mentioned earlier, assembly team and debugging $\&$ inspection team do most of the jobs in the main production line and they are responsible for assembling, debugging and inspecting of every color TV set. The number of workers in assembly team and debugging \& inspection team is about 40 and 30 respectively. Packing team boxes the finished TVs. And the number of workers in the processing team varies (with a minimum of six workers, a maximum of more than 20 workers, and an average number of 11 workers), depending on the types of TV cabinets needed. Other workers who do not belong to any of the above four teams help team members with packing and boxing finished TV sets. In TCL's workshops, packing team is nicknamed as the big "bottleneck position". The whole production line can speed up if working efficiency in this step is improved.

\subsubsection{Reasons for CTV.F's fast production speed}

First, cut non-value added time. Traditionally, the working time in production lines can be classified into value added time and non-value added time. The former refers to the manual assembly time for color TV; the latter refers to the transfer and waiting time when semi-finished products are carried among different working positions. In order to reduce takt time and non-value added time, workers need to first shorten manual assembly time and to cut the semi-finished product transfer time by adding accelerating wheels between neighboring working boards (to reduce workers' waiting time). In the past, when assembling TVs, workers needed to turn the TVs' on the conveyor, resulting in a waste of time. To solve this problem, technicians adjusted the angle of workers' seats so that workers along the assembly line can face TVs to be assembled directly. Thus the non-value added time of turning TVs decreased. In addition, while designing the production line, the general engineer of TCL invented a new type of signal coupler which can reduce the time of repeatedly inserting and pulling plugs. Second, greatly improve the working efficiency of bottleneck positions. Production rhythm is mainly determined by the working 


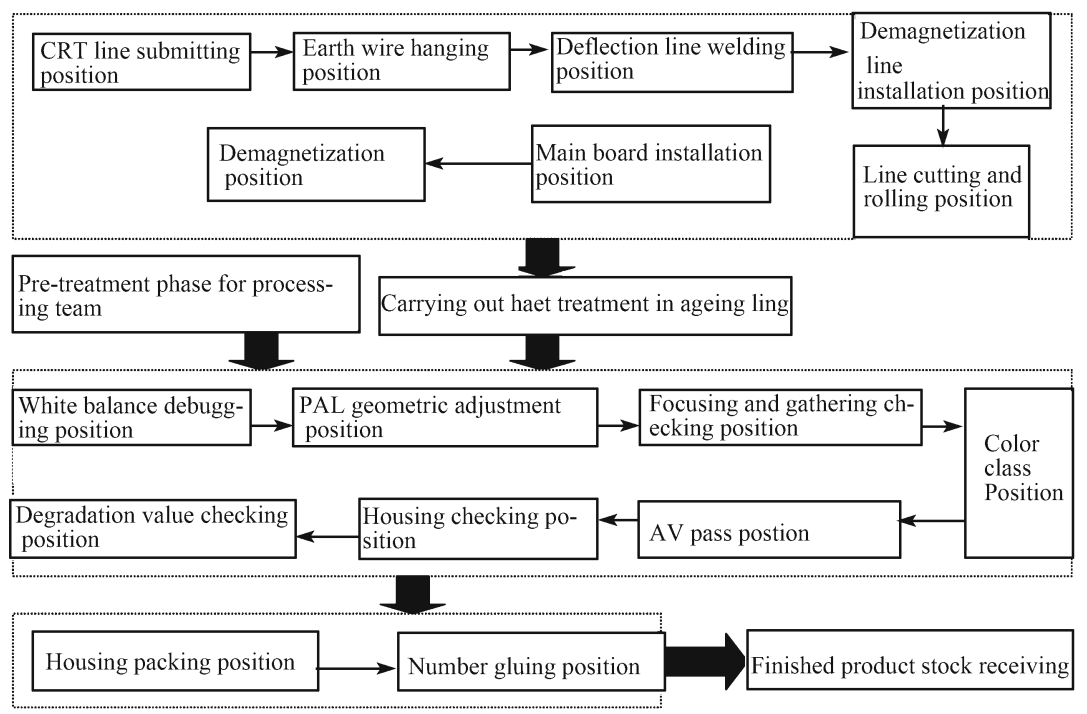

Fig. 3 Process flow of TCL's color TV production line Source: Drawn based on research and field observation.

efficiency of bottleneck positions, like the packing position we mentioned above. By perfecting the sucking and slinging devices at the packing step and by installing new types of automatic case sealers, the working efficiency of the packing team is greatly improved, thus the production rhythm of the whole production line is meliorated. Third, batch production of the same model of TVs. Production rhythm is closely related to the model of products produced and batch quantities. Given the same production equipment and techniques, the larger a batch is, the faster the production rhythm is. Since smaller TVs like the 21 " model are of mature model and are comparatively easier to make, to raise production speed, the fast production line is mainly used to produce large batches of smaller models, while TVs bigger than 29", small batches, or TVs with complicated design are mainly produced on other production lines. Fourth, specific and definite labor division. Comparatively speaking, the labor divisions among fast production line workers are more specific, definite, and efficiency-oriented than common production line workers. Take the deflection wire welding and inserting job as an example, common production line workers are responsible for both welding and inserting the deflection wire, while the same work on fast production line is divided into two work positions and is done separately by two workers. Generally speaking, the number of workers on fast production line is about 100 , approximately 10 more than ordinary production lines. 


\section{Transparent, open and quantified management style}

\subsection{Morning meeting and working hours}

The working hours for TCL Huizhou production base are 8:00-12:00, 13:00-17:30. 12:00-13:00 is noon break and Saturday and Sunday are resting time. As production task is full, actual off duty time for workers in average is around 19:00 and there are only one to two days off per month (extra pay is offered for overtime working, see also Section 4). Workers usually arrive at plant at around 7:45 and the production line leader holds a 10-min morning meeting. First, line leader and all his workers sing TCL song together; then the line leader leads the workers to read aloud morning meeting teachings (the contents of morning meeting teachings include some catchwords proposed by managers and some words from workers, see Appendix 3 for details), in the end, the line leader summarizes working performance of previous day, with making some blames and praises to workers. He/She then announce the production task, product model, batch quantity and quality required for the new day. Morning meeting ends at 7:55. Every one goes back to his/her position and makes preparation for a new day's work. At 8:00, the production line starts to operate and everyone gets into busy and ordered work 5 .

Intervals of 10:00-10:15 a.m. and 15:00-15:15 p.m. are break time. Usually, Workers Union and Youth Lague Committee of CTV Workshop for Domestic Sales use this break to do some recreational activities, such as holding a miniature Karaoke singing competition (three to four workers sing at each break time, the first, second and third winner are rewarded). During our visiting to the plant (November 27-29, 2002), we saw a push-and-pull contest played between different production lines, with the line leaders acting as referees. Workers not attending the game were organized as cheerleaders. We could feel the excitement in the air. In addition, considering Guangdong' weather is fuggy and humid in summer and workers are prone to heat-stroke, plant cafeteria provides free cool tea or mung bean soup for workers in the afternoon.

\subsection{Kanban management}

In CTV production workshop, at the end of each production line there is a Kanban (notice board) hanging over showing the "latest production progress". Dynamic

\footnotetext{
${ }^{5}$ Authors Ouyang Taohua and Li Jiahong attended the morning meeting of fast production line on November 27, 2002. Both of them felt the impact of cohesion and enthusiasm from these first-liner workers and managers.
} 
operating condition of each production line can be learned through this notice board. Take the information list on the CTV.F line Kanban on November 27, 2002 as an example (as shown in Table 2), the line leader fills the list every hour in items such as planned quantity, actual quantity, quantity short (use black-color numbers) /over (use red-color numbers), defect rate, failure reason analysis, problem handler (person responsible for handling the problems of unfinished work), etc. As such, the notice board can clearly demonstrate differences between planned output and actual work progress and defect rate. In principle, no matter with what reasons daily planned production task must be achieved. If the planned output is not reached in a certain hour, it needs to be explained and improvement measures shall be put forward during the failure reasons analysis meeting. Through kanban management, dynamic information of production site is transmitted to each worker in the most direct way, and problems existing at site and improvement measures of the problem solver are fully exposed to the supervision of all workers.

\subsection{Contract between master and apprentice, and training of workers}

"Contract between master and apprentice" means a kind of method to train new workers through the establishment of contract relationship as master and apprentice between experienced worker and new worker within a certain period of time (about one month). The experienced worker is responsible to teach his new pupil until the latter has acquired enough skills to do his job. The workshop director works as a notary and the line head assigns new workers to experience workers as their apprentice. During the first week, the new worker stands beside his master, observing actions of the master. A week later, the apprentice is allowed to have a try on his own. The master teaches his apprentice techniques in his spare time. "Compact between master and apprentice" is suitable not only for new workers, but for veteran workers. In the case of a veteran worker is transferred to a new working position, he may also need to learn new skills from a master. In the end, an operation skills examination for new workers will be held by the line leader. The masters of those excellent new workers will be rewarded accordingly.

\subsection{Transparent, open and quantified appraisal mechanism}

\subsubsection{Composition of employee salary}

In TCL, an employee's salary consists of three parts, namely basic salary, performance bonus and overtime pay (salary income $=$ basic salary + overtime pay + performance bonus). Basic salary for every contracted worker is more or 
Production system and competitive power of Chinese enterprises

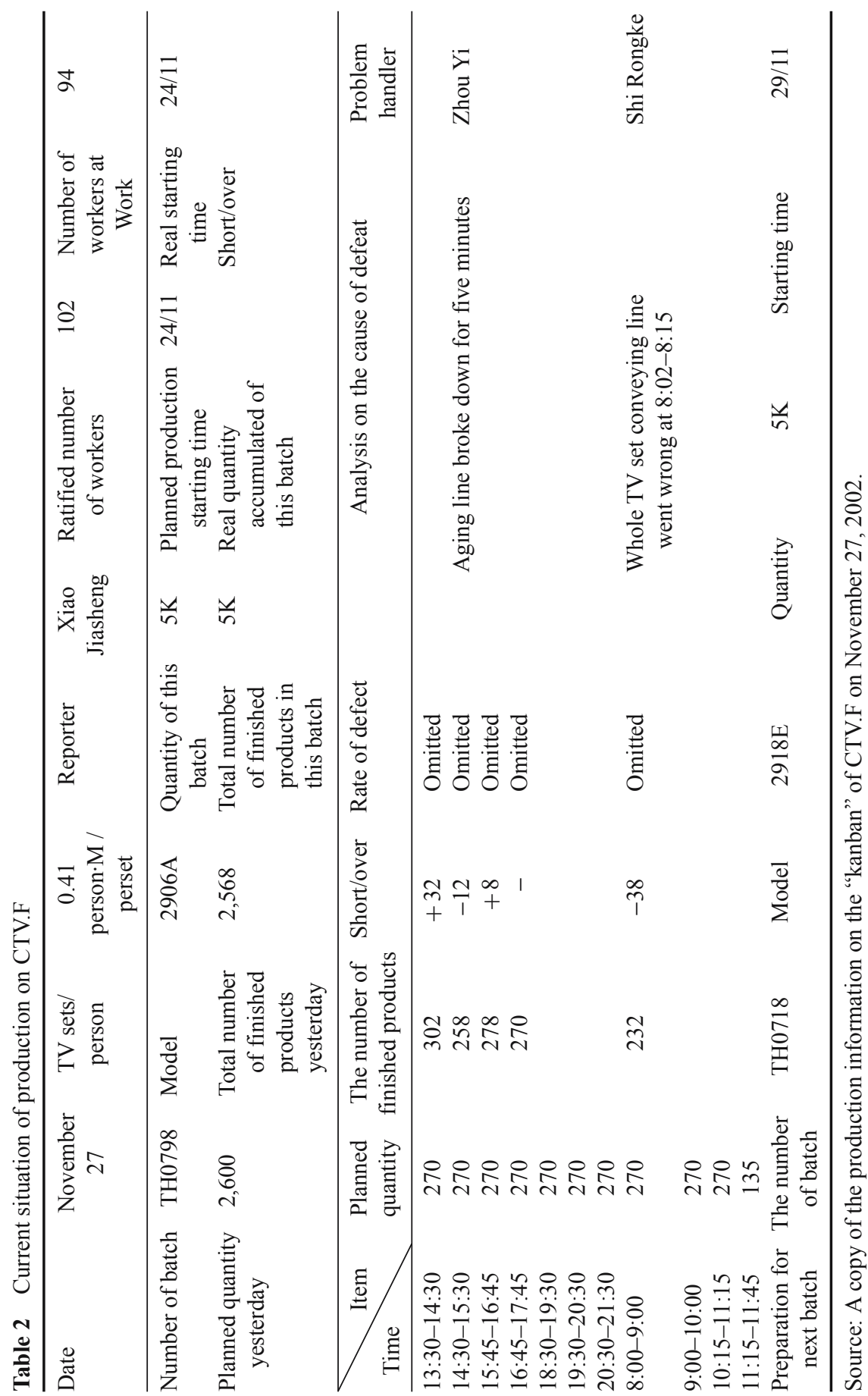


less the same, about $580 y_{u a n^{6}}$. Overtime pay mainly means the payment gained through overtime work on public holidays and legal holidays. Specifically, overtime pay on Saturday and Sunday is twice and three times that of the basic daily salary respectively. Production line workers can normally get the same basic salary and overtime pay so long as they attend on time and work hard. As overtime pay is relatively high, most workers are willing to work overtime.

The calculation of performance bonus is complicated, which is related to a series of items such as color TV models produced, products quantity and quality, etc. Performance bonus is granted every month. Its calculation formula is: performance bonus $=$ basic performance bonus $\times$ performance bonus readjustment factor. Basic performance bonus represents the average amount of performance bonus for workers on the same production line. Basic performance bonus $=$ (quantity produced $\times$ the unit price of TV produced - material consumed - working hours cost of borrowed workers)/the number of workers on line. There are three key factors affecting basic performance bonus: first, the quantity of qualified color TV produced in a month and the internal accounting prices of these TVs. Internal accounting price is the unit price of color TV made inside the company for the convenience of calculating the overall performance of a production line. The price varies in accordance with TV models and TV's market price. In general, color TV model with high market price also has a high internal accounting price in the company. Total quantity of different models of TVs produced in one month times their internal accounting prices is the gross income of a production line. Second, material consumed, which refers to the cost of component parts used in manufacturing. This index is mainly used to control manufacturing cost. The more material waster is, the higher the manufacturing cost. The basic performance bonus of workers on a certain production line will increase if the manufacturing cost is reduced. Third, working hours cost of borrowed workers from other production lines. When the task on one production line is full and other production line workers are borrowed, other production lines need to be paid for their workers working hours. Given production line workers are stable in number, the quantity of color TV produced and the internal accounting price per TV set are the determinants of a worker's basic performance. Theoretically, basic performance bonus for all workers on the same production line shall be the same. But TCL classifies its workers into three groups as A, B and $\mathrm{C}$ based on the results of working performances appraisal. The top 20\% of workers with highest performance scores are marked as groups A, last $20 \%$ as group C, and the other $60 \%$ in the middle as group B. Different groups of workers

\footnotetext{
${ }^{6}$ Basic daily salary is 20 RMB yuan. Since the number "58" stand for good luck in China (pronunciation of the number sounds like "you will make a fortune"), a monthly fixed basic salary of 580 yuan is accepted.
} 
get different performance bonus adjustment factor. Specifically, workers in group A get $120 \%$ of the basic performance bonus. Workers in group B and group $\mathrm{C}$ get $100 \%$ and $80 \%$ respectively.

Taken together, the basic performance bonus of workers on different production lines varies while workers work on the same production line get the same performance bonus. But because workers will be classified into different groups based on their performance appraisal results, even in the same production line, group A workers get $40 \%$ more performance bonus than that of group $\mathrm{C}$ workers. Moreover, workers appraised as group $\mathrm{C}$ for three months in a row will be fired. On average, production line workers can get a salary of about 1,500 RMB yuan each month, including 580 yuan basic salary, several hundred yuan as overtime pay, and a basic performance bonus fluctuating around 500 yuan.

\subsubsection{Workers performance appraisal}

The workers performance appraisal of TCL color TV production system originally followed the example Hong Kong enterprises and focused on production rhythm and efficiency. Product quality and production efficiency were emphasized greatly. In 1998, when Huizhou production base was put into production, Japanese kanban management, and 6S management (adding a new "S" (safety) into the original Japanese 5S management) was introduced. TCL's criteria for appraising workers' performance evolved from merely emphasizing product quality and quantity into a more comprehensive and scientific appraisal system consisting of four parts, namely worker quality, product quality, $6 \mathrm{~S}$ management and working discipline. The first thing is worker quality. Production line workers are required to obey leaders, finish their own jobs, comply with factory rules and regulations, and offer help when neighboring workers are busy. The second thing is product quality. Production line workers are required to guarantee product quality. To insure product quality, King Huizhou implements a three-step examination system namely self-checking, mutual checking and overall checking. Different quality problems on production line are classified into class $\mathrm{A}, \mathrm{B}$ and $\mathrm{C}$ in accordance with the order of problem seriousness. Class A stands for severe quality problems, class B for normal quality problems and class $\mathrm{C}$ for minor quality problems. Standards to judge these three classes of quality problems are officially published and understood by each worker. The product quality inspection and evaluation right goes to the quality assurance department. If class A quality problem occurs at certain working procedure, workers in charge of this procedure will be deducted three points; and one point for class B problem. As for class $\mathrm{C}$ problems, it is required to correct them on the spot and no point will be deducted. If the quality problem of certain procedure is checked out by workers 
of the next procedure, the problem detector will gain half of the points deducted from the workers at the previous procedure, that is, 1.5 points for class A problem and 0.5 point for class B problem. This policy is designed to encourage workers of next procedure to check quality problem of previous procedure. If next procedure failed to detect quality problem made by the previous procedure, while the quality inspector checked it out, the worker of next procedure will be deducted 1.5 points for class A problem and 0.5 point for class $\mathrm{B}$. Third, " $6 \mathrm{~S}$ " management. Production line workers are required to keep the working environment clean, take good care of the machinery, and pay attention to grooming and personal hygiene. While at work, workers need to maintain the tidiness of the production line and help dustmen clean the plant. They are also required to tidy up everything and put components and tools to their right positions before going home. The fourth one is working discipline. Major discipline includes that each worker should understand well his job and be able to operate skillfully, and meet the production requirements; female workers are required to wear kerchiefs; workers working on TV cabinet shall wear gloves and over sleeves (to avoid static electricity); no watches and finger rings are allowed in working hours; workers shall wear working shoes at work; males cannot have long hair and females cannot have their hair pigmentized; the zipper of the working uniform cannot be lower than the position of working card hung on the chest, etc. worker quality, working discipline and $6 \mathrm{~S}$ management are evaluated by team leader and line leaders according to relevant specifications and rules. As workers in CTV workshop for domestic sale can abide by all the above rules well, usually they will not be deducted any points. Product quality is the main cause of point deduction and the inspection on product quality is carried out most strictly. When quality problems occur, workers responsible for the mistake will face point's deduction immediately and need to sign and confirm the fault with team leader after work (see Appendix 4). Basic performance scoring for each worker on production line is 85 points. Workers are appraised comprehensively on the above four standards. Scores are added or deducted in accordance with individual performance. Total monthly points for production line worker $=85 \pm$ performance appraisal score. At the end of each month, TCL classifies the production line workers into three groups of A, $\mathrm{B}$ and $\mathrm{C}$ based on his monthly performance appraisal scores.

\subsubsection{Performance appraisal for managerial personnel}

Performance appraisal for first line managerial personnel (team leader, line leader and workshop director) adopts the key performance index (KPI) appraisal system, which includes three indices: product quality, cost control and production efficiency. Cost control index takes standard model as a parameter and requires unit cost to be reduced constantly. The workshop director is the very person 
responsible for the cost control measures in his workshop. Commitment scheme is signed on the basis of negotiation between supervisors and subordinators to make sure the cost control measures will be implemented effectively.

Performance appraisal for managers mainly focuses on product quality. TCL divides its managerial personnel into three grades, namely Grade A, B and C, with a percentage of $15 \%, 70 \%$ and $15 \%$ respectively. Performance bonus is paid on the basis of these grades. Grade A managers get $25 \%$ more performance bonus than that of Grade $\mathrm{C}$ and managers get grade $\mathrm{C}$ appraisal three times in a row will be fired.

\subsubsection{Improvement of the performance appraisal system}

In 2003, the other six common production lines in general assembly workshops (CTV workshops) of King Huizhou successfully duplicated the production techniques and management modes of the fast production line. As a result, the production efficiency of these production lines is raised to $15 \mathrm{TV}$ sets per second. In the same year, TCL's performance appraisal indices evolved from the former four items (worker quality, production quality, working disciplines and 6S management) into three items (5S, product quality and quantity). Performance score is calculated on the very day after work, and the workers are put accordingly into class A, B and C (See Table 3). One of the principal causes for the reduction of appraisal indices is that with the improvement of production line workers' quality, some formerly emphasized rules of daily behaviors are now generally observed by workers as common senses. Under such circumstances, to appraise whether workers have abide by these basic rules becomes pointless. In addition, the performance appraisal for workers is conducted on a daily basis rather than on a monthly basis.

Table 3 Monthly performance appraisal form of the AIS workshop of Huizhou TV factory

\begin{tabular}{|c|c|c|c|c|c|c|c|c|c|c|c|c|c|}
\hline & Date & 1 & 2 & 3 & 4 & 5 & 6 & 7 & 8 & 9 & 10 & 11 & 12 \\
\hline \multirow[t]{4}{*}{ Worker A } & $5 \mathrm{~S}$ & & & & & & & & & & & & \\
\hline & Quality & & & & & & & & & & & & \\
\hline & Quantity & & & & & & & & & & & & \\
\hline & Grade & & & & & & & & & & & & \\
\hline \multirow[t]{4}{*}{ Worker B } & $5 \mathrm{~S}$ & & & & & & & & & & & & \\
\hline & Quality & & & & & & & & & & & & \\
\hline & Quantity & & & & & & & & & & & & \\
\hline & Grade & & & & & & & & & & & & \\
\hline
\end{tabular}

Source: TCL internal information. 
Besides, three changes were made as below. First, the standard working hours scheme is introduced. In 2003, a committee for standard working hours scheme was founded with aims of measuring and standardizing working hours and working flow at different procedures on the production line. With standardized working hours and working flow, it is easier for production line workers to improve their working efficiency. Also, the measuring of standard working hours reflects the difficulties and degrees of importance of different work along the production line and makes the comparison of works between different positions possible. Second, changes are made in performance appraisal methods. Performance scores for production line workers increased to 100 points and performance appraisal became more specific. Moreover, qualitative changes were made in the new appraisal system: the previous system was punishment oriented. In contrast, the new appraisal system is more praise-oriented. Except for economic punishment for product quality problems, most appraisal results are accompanied with certain rewards in one way or another, implying the new principle of "no-reward equals to punishment". Third one is red flag rank and washing-out policy. A rank of different production lines is made in each workshop according to the percentage of accomplishment of production plan and product quality. The check on production plan accomplishment and product quality is carried out and results are calculated every day. Each production line's performance is appraised by means of aggregating the production plan accomplishment and product quality checking results of each line worker. Workers of the top four production lines will be rewarded with different amount of bonuses. For example, in November, 2006, workers on the fast production line (line F) got a reward of 30 yuan each owing to their No. 1 position in the monthly production plan accomplishment rank (See Table 4). If a production line ranks last for three months in succession, the production line leader will be washed out.

Table 4 Checklist for production plan accomplishment

\begin{tabular}{lcccrrrr}
\hline $\begin{array}{l}\text { Production } \\
\text { line }\end{array}$ & $\begin{array}{c}\text { Planned } \\
\text { daily } \\
\text { output }\end{array}$ & $\begin{array}{c}\text { Daily plan } \\
\text { accomplishment }\end{array}$ & $\begin{array}{c}\text { Planned } \\
\text { monthly } \\
\text { output }\end{array}$ & $\begin{array}{c}\text { Total } \\
\text { monthly } \\
\text { output }\end{array}$ & $\begin{array}{c}\text { Daily } \\
\text { balance }\end{array}$ & $\begin{array}{r}\text { Total balance } \\
\text { ranking }\end{array}$ & Daily \\
\hline A & 1,400 & 1,200 & 41,670 & 34,028 & -180 & $-6,642$ & 2 \\
B & 1,600 & 560 & 41,743 & 34,548 & $-1,040$ & $-7,195$ & 7 \\
C & 1,566 & 666 & 41,886 & 33,898 & -900 & $-7,988$ & 6 \\
D & 1,554 & 954 & 43,590 & 36,515 & -600 & $-7,075$ & 5 \\
E & 1,300 & 875 & 36,363 & 26,244 & -425 & $-10,119$ & 4 \\
F & 2,600 & 2,566 & 78,000 & 80,239 & -64 & 2,239 & 1 \\
U & 600 & 266 & 16,850 & 7,460 & -354 & $-9,390$ & 3 \\
\hline
\end{tabular}

Source: A copy of the "Checklist for production plan accomplishment" of the CTV workshop on November 25, 2002". 


\section{Case analysis and fact findings}

Over a short period of a bit more than a decade, TCL has expanded from a tiny plant with an annual capacity of only 1,500 color TV sets to one of the biggest and most efficient color TV makers in the world. How did TCL build its world-class production system and gain world competitiveness within such a short time? Through the above description of the production system of TCL King Color TV, we found the following three reasons.

\subsection{Advantage of backwardness and creative imitation}

The concept of advantage of backwardness is proposed by A.Gerchenkron. He found out that the industrial revolutions in late-developing countries usually start first in relatively advanced industries of early-developing countries. Because with the technological innovation, the production equipment of first-moving companies may be lagged behind, but even so the equipment is not easy to be disposed of. The production equipment and production efficiency of first-moving companies do not have absolute advantages in the relatively advanced industries. When late-moving companies enter an industry characterized by relatively advanced technology and rapid development, they stand on a relatively favorable competitive position compared with early-moving companies as they are equipped with the latest production machines and technology.

TCL Group entered the color TV industry in 1992. At that time, $18^{\prime \prime}-21^{\prime \prime}$ color TVs were the mainstream TV sets in the market and color TV above $25^{\prime \prime}$ was monopolized by oversea brands. Realizing that the demand for big screen TVs will boom as the people's living standards improve constantly, TCL decided to manufacture big screen color TV directly. The first batch of $28^{\prime \prime}$ big screen color TV was produced in OEM way. When there is a good market prospect for large-screen color TV, TCL started to construct its own color TV production base in 1996, equipped with the most advanced production techniques and key production equipments at that time. Started from 1998, TCL shifted its focus to the systematic learning of advanced management thoughts and practices from American and Japanese companies (mainly including total quality management, 6S campaign, kanban management, and so on) to improve its production efficiency and product quality. From 2003, TCL further reformed and bettered its management mode. It conducted a series of experiments on the working hour and motion of each working position and standardized the labor strength and motion of each working position. These studies laid a preliminary foundation for TCL's future lean management reform.

Meeting of market needs, integration of necessary resources and utilization of advantage of backwardness are the secret of TCL's leap-forward development within such a short time. Among these preconditions, the utilization of advantage 
of backwardness is the sufficient condition for the rapid development of TCL's color TV division and other Chinese household electric appliance enterprises.

\subsection{Fast duplication capacity}

From 1996 to 2000, TCL quickly established five domestic production bases. The fast production line in Huizhou King TV Production Base is the test field for TCL color TV production system. The innovation of management manners is usually tried first on the fast production line. When necessary experiences are obtained, the new managerial practices will be extended to CTV workshops, and then promoted to other TCL color TV production bases, or even to TCL Mobile and other non-color TV manufacturing divisions. For example, the Kanban ${ }^{97}$ system, as part of the campaign for continuous site improvement, was first tried in CTV workshops. And then it was extended to other production lines and workshops when the efficiency of the Kanban system was proved.

After the merger of other domestic color TV companies, TCL usually copies its color TV production techniques, staff management mode, and incentive mechanism to the merged companies to arouse the vitality of its workers. Meanwhile, TCL's competitiveness gets strengthened from the aspects of product quantity, quality, cost control, delivery time, etc.

\subsection{Marketized performance appraisal system}

The operation management of TCL King color TV has the following characteristics. (1) Decompose company goal into smaller sub-goals and assign them to each worker. Each worker is treated as an independent appraisal unit. Managers make sure that the appraisal standards are clearly understood by every worker. The appraisal system of TCL King color TV is noted for its open, scientific, fractionized and quantified appraisal indices and transparent appraisal results. (2) Evaluation results are shown by scores and used as a distribution basis for basic performance bonus. It also explains the income gaps among the workers. (3) Performance bonus for each production line is not fixed and is related dynamically with market benefit and manufacturing cost control. (4) An effective competition and elimination mechanism makes sure "ordinary" yet capable workers will be promoted to key positions, or as team leader, line leader or even workshop directors. It also washes out those unqualified managerial personnel. For example, in TCL, first-line managerial personnel at all levels will be demoted if he/she positions last in the rank three times in a row.

\footnotetext{
${ }^{7}$ Carried out in the second half year of 2003 , workers in charge will record down the product quality problems, problem solving suggestions, improvement goals and measures, and amendment results and other production-related information. They are also required to trace the above information and seek feedback on a daily basis.
} 
The management style of TCL King color TV is different from that of American and Japanese enterprises. In America, self-management of workers and market benefit are emphasized, and motions and techniques at each procedure of production process are required to be scientific and quantified, while the management of workers on production line is carried out more through relatively fixed hour wages or weekly wages. Traditional Japanese management of workers is not based on individual position, but on individual educational level and the number of years of continuous service in the company. Japanese enterprises usually adopt a fixed salary system. At the end of the 20th century, with the introduction of more results-oriented management philosophy, Japanese management style started to change. However, the performance bonus in Japanese workers' salary still accounts for less than $15 \%$ and most Japanese enterprises still stick to the fixed salary system. In addition, Japanese management stresses team work and is characterized by long-term and non-monetary incentives. In comparison, TCL color TV production system management attempts to be scientific and quantified in the aspect of material management. The same principle is also applicable to the management of workers. TCL emphasizes the quantified performance appraisal of each worker and links employee performance appraisal with corresponding market benefits.

\section{Conclusion}

The competitive power of TCL color TV production system mainly comes from its formation of economy of scale within a short time and its highly efficient production system. The reasons for this quick competitiveness formation include the following three aspects: advantage of backwardness and creative imitation, fast duplication capacity, and a marketized performance appraisal system. Specifically, the utilization of the advantage of backwardness is the sufficient condition for TCL color TV division's leap-forward growth. The duplicable operation capacity and marketized performance appraisal system are among the core competences of TCL. By transmit the market competition pressure to every production line worker by means of a dynamic performance appraisal system, TCL successfully motivates every worker.

Using Professor Fujimoto's framework to analyze the competitiveness of TCL, we found the forming of TCL's color TV productivity has experienced three stages (see Table 5): (1) static manufacturing capability (before 1998); (2) dynamic improving capability (1998-2002); and (3) evolution capability (after 2003)-a marketized performance appraisal system.

In general, there is an obvious distance between China's manufacturing industry and the manufacturing industry in developed countries. Most of Chinese manufacturing enterprises, when compete in domestic and international market, 
Table 5 TCL King color TV production mode

\begin{tabular}{|c|c|c|c|}
\hline $\begin{array}{l}\text { Level of } \\
\text { capability }\end{array}$ & Basic property & $\begin{array}{l}\text { Brief history of } \\
\text { capability formation }\end{array}$ & $\begin{array}{l}\text { Interpretation of the } \\
\text { competitiveness }\end{array}$ \\
\hline Static capability & Static reproduction & $\begin{array}{l}\text { After over the acquisition } \\
\text { of Luks Group's color } \\
\text { TV business, TCL } \\
\text { acquired gradually } \\
\text { the steady and static } \\
\text { competence of color } \\
\text { TV production and } \\
\text { development }\end{array}$ & $\begin{array}{l}\text { Under normal } \\
\text { conditions, enterprises' } \\
\text { product development } \\
\text { and manufacturing } \\
\text { system can process } \\
\text { product manufacturing } \\
\text { information repeatedly, } \\
\text { accurately and } \\
\text { effectively }\end{array}$ \\
\hline $\begin{array}{l}\text { Improvement } \\
\text { capability }\end{array}$ & $\begin{array}{l}\text { Dynamic } \\
\text { reproduction }\end{array}$ & $\begin{array}{l}\text { Huizhou TCL King } \\
\text { color TV production } \\
\text { base was completed } \\
\text { in 1998, and TCL } \\
\text { started to learn and } \\
\text { duplicate systematically } \\
\text { Japanese production } \\
\text { mode; after the } \\
\text { completion of Huizhou } \\
\text { Production Base in } \\
\text { 1998, TCL started } \\
\text { to systematically learn } \\
\text { and copy Japanese } \\
\text { operation management } \\
\text { mode (i.e. Kanban } \\
\text { and 5S management } \\
\text { etc.); then it spread } \\
\text { these new management } \\
\text { modes to other color } \\
\text { TV production bases, } \\
\text { even to the TCL } \\
\text { cellphone business; } \\
\text { thus it formed gradually } \\
\text { a self-improvement } \\
\text { manufacturing } \\
\text { system of its own }\end{array}$ & $\begin{array}{l}\text { It can not only } \\
\text { solve problems quickly } \\
\text { and efficiently, but } \\
\text { also handle static } \\
\text { information }\end{array}$ \\
\hline $\begin{array}{l}\text { Evolution } \\
\text { capability }\end{array}$ & $\begin{array}{l}\text { Innovation and } \\
\text { inimitableness }\end{array}$ & $\begin{array}{l}\text { Build the competitiveness } \\
\text { quickly and make } \\
\text { sure it works }\end{array}$ & $\begin{array}{l}\text { Having the genes } \\
\text { for creation capability } \\
\text { building; the capability } \\
\text { is also evolving } \\
\text { constantly and thus } \\
\text { it is inimitable for } \\
\text { other enterprises }\end{array}$ \\
\hline
\end{tabular}


still depend on cheap labors and passive imitation of the first runner in the industry. How to greatly enhance the production competitiveness of China's manufacturing enterprises within a time. Our case study on TCL's color TV production system may provide some suggestions: first, make full use of the advantage of backwardness to form quickly a creative imitation capacity and self-improvement operation ability; second, establish a maketized performance appraisal system. Thus the invisible hand of free market will motivate every worker and transmit market pressure to them. As an old saying goes, "armies in which superiors and subordinates share the same goal win the war." When the working staff gets united closely around market goals, an enterprise becomes invincible in the competition. The marketization of internal management requires a fair-play platform within the enterprise, a reasonable and transparent management mechanism, and a marketized performance appraisal system.

The formation of TCL's world-class manufacturing competence is a direct result of the perfection of a series of interrelated systems such as manufacturing system, R \& D system, logistics system, etc. Due to space limit, this paper only probed into the competitive advantage of TCL from the aspect of production system, namely the structure of color TV fast production line and relevant work flow and staff management. But how does TCL's products development system coordinate with the logistic system, and, how does the color TV R\&D system match and coordinate with logistics system and manufacturing system? All these questions remain unanswered in the present article and future research on these topics is needed.

Acknowledgements This research is sponsored by a general program from the National Natural Science Foundation of China (Program title: Theoretical and empirical studies on the comparative advantage theory of competition, Grant No.: 70772092).

\section{References}

Barney J B (1991). Firm resources and sustainable competitive advantage. Journal of Management

Barney J B (1991). Firm resources and sustained competitive advantage. Journal of management, 17(1): 99

Dierickx I, Cool K (1989). Asset stock accumulation and sustain ability of competitive advantage. Management Science, 35(12): 1504-1511

Fujimoto T (1999). The evolution of a manufacturing system at Toyota. New York: Oxford University Press, 17

Fujimoto T (1999). The Evolution of A Manufacturing System at Toyota. Oxford University Press

He Feng, Feng Zongxian, Chen Rong (1999). Comparative study on the manufacturing industry's competitiveness between Chinese state-owned enterprises and foreign invested enterprises. Company Decision, 9 (in Chinese)

Kantrow A M, George C; Levitt Jr A (1983). The political realities of industrial policy. Harvard Business Review, 61(5): 76-86 
Li Sheng. Study on brand development problem of TCL group. Journal of Inner Mongolia Industrial University (Social Science Edition), 9(2) (in Chinese)

Mao Yunshi, Ouyang Taohua, Wei Guozheng (2004). Competition advantages of China household electric appliances company — a case study on Glanz. Management World, 6 (in Chinese)

Nelson R R, Winter S G (1982). An Evolutionary Theory of Economic Change. Cambridge, Mass: Belknap Press of Harvard University Press

Ouyang Taohua (2004). Case study method in the field of business administration. Nankai Business Review, 2 (in Chinese)

Peteraf M A (1993). The cornerstones of competitive advantage: A resource-based view. Strategic Management Journal, Mar 93, 14(3): 179-191

Porter M E (1985). Competitive Advantage. New York: The Free Press, 20

Qu Xiaoyu (2001). TCL Mobilephone: Dare to be a trailblazer, strategy deciding the world. Light of Quality, (in Chinese)

\section{Appendix 1 Organization chart of TCL Group}

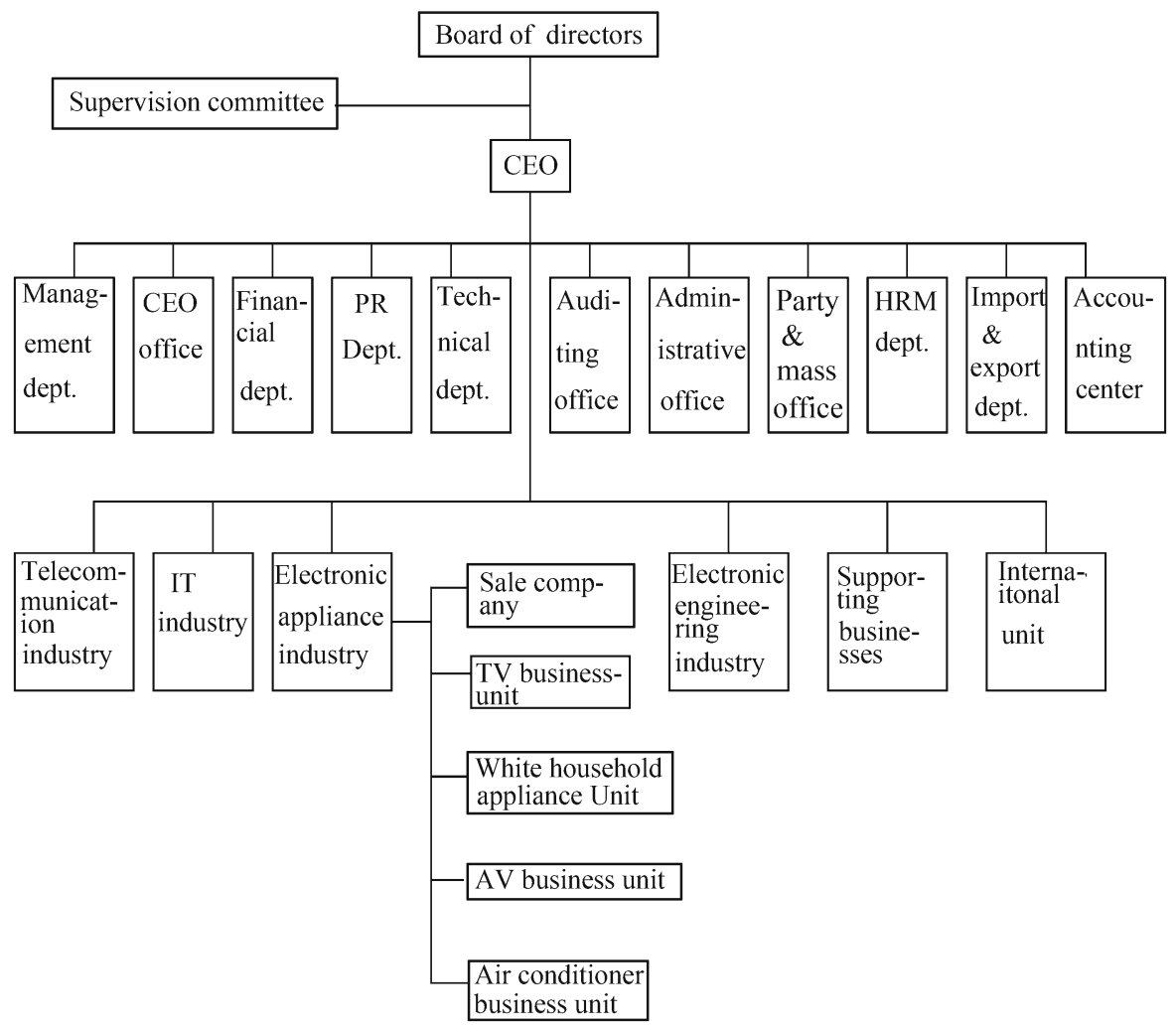

Source: TCL internal information. 


\section{Appendix 2 Organization chart of TV business unit}

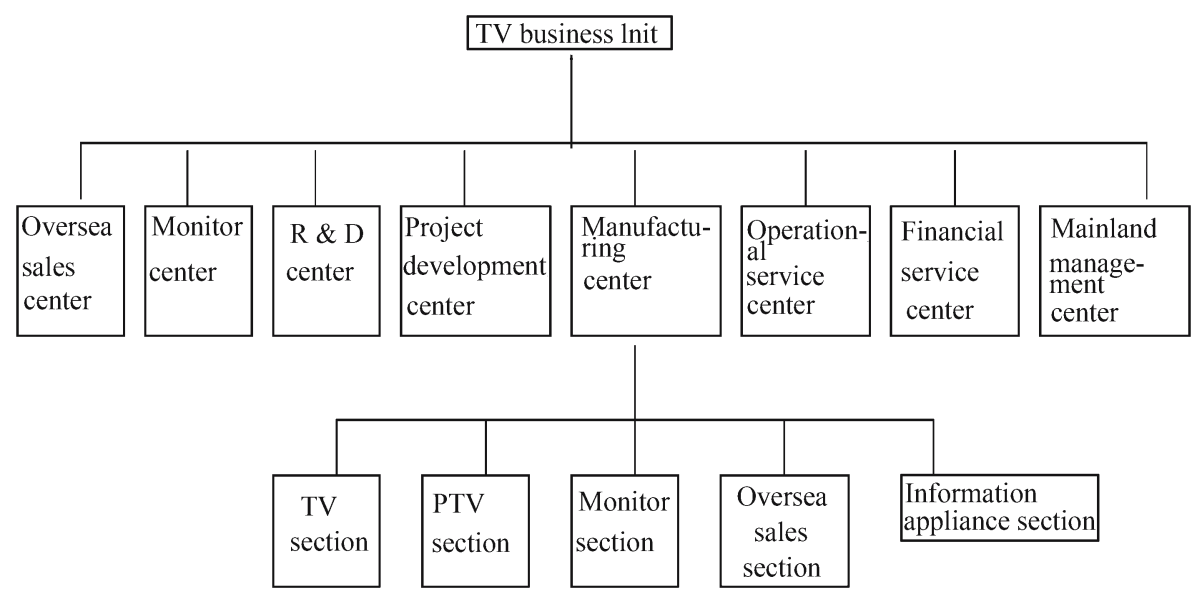

Source: TCL internal information.

\section{Appendix 3 Selection from morning meeting teaching}

Everyday has a new start. Everyday has a new hope.

Focus on your job, input fully and it will make you full of vitality.

Do not waste your time on anxiety of possible failure.

United, fight, and win!

Learning is the key to progress and unemployment is the result of laziness.

Actions are one thousand and one times better than unpractical daydreaming.

Have the courage to admit mistakes and make improvements, have a love heart with tolerance and encourage.

One "today" is better than two "tomorrows".

To work is a problem only for those lazy persons.

Do well the safety and prevention work for the sake of our company and for the sake of yourself.

One percent quality problem is a hundred percent loss to the client.

No quality, no future.

Make best products with lowest cost.

Workers at the next procedure are my customers.

Raise production and quality, improve working environment.

People complain most are usually people achieve least.

Person who regards himself as very hardworking always neglects his own duty.

Steadfast working attitude is the basic guarantee for product quality.

Techniques are the law of the factory. Neglect of techniques is violation of law.

Do not work hard today, find a work hard tomorrow.
Feng Yongzhong

Zhong Yaozong

Liao Luzhao

Liu Jian

Li Junwei

Luo Fusheng

Gong Yuanxia

Yang Mei

Yuan Qiongqiong

Wang Yufeng

Run Hongmei

Ye Hongying

Li Yanyu

Li Cuifang

Huang Sanlong

Ye Hongying

Chen Yun

Sun Jun

Office

Office 


\section{Appendix 4 Products quality grading and appraisal}

\begin{tabular}{|l|l|l|l|l|l|l|}
\hline Month & Date & Name & Type & Analysis of causes for repair & Number & Penalty \\
\hline & & & & & & \\
\hline & & & & & & \\
\hline & & & & & & \\
\hline & & & & & & \\
\hline & & & & & & \\
\hline & & & & & & \\
\hline & & & & & & \\
\hline
\end{tabular}

\section{Appendix 5 Date and Interviewees of Survey}

\begin{tabular}{|c|c|c|}
\hline Date & Interviewers & Interviewees \\
\hline July 29, 2002 & $\begin{array}{l}\text { Mao Runshi, Ouyang } \\
\text { Taohua, Wang Jiancheng } \\
\text { and Li Jiahong }\end{array}$ & $\begin{array}{l}\text { CEO Office: Mao Xiao, Kang Hong } \\
\text { Administrative Office: Zhang Hanfeng }\end{array}$ \\
\hline $\begin{array}{l}\text { October 10-11, } \\
\quad 2002\end{array}$ & Li Jiahong & $\begin{array}{l}\text { TCL co-founder: Huang Pingchu } \\
\text { TCL Best Worker: Zhang Denghong } \\
\text { TCL CTV Workshop Director: Zhong } \\
\text { Weixian }\end{array}$ \\
\hline $\begin{array}{l}\text { November } 25-27 \text {, } \\
\quad 2002\end{array}$ & $\begin{array}{l}\text { Ouyang Taohua, } \\
\text { Li Jiahong }\end{array}$ & $\begin{array}{l}\text { TCL CTV.F Line leader: Xiao Jiasheng } \\
\text { TCL CTV.A Line leader: Su Qiaomei } \\
\text { TCL CTV.F Line Best Worker: Liu Naiduo } \\
\text { TCL CTV.C Line woker: Zhang Xiaolin } \\
\text { TCL CTV.F Line worker: Zhang Xia }\end{array}$ \\
\hline April 10, 2003 & Li Jiahong, Han Fang & $\begin{array}{l}\text { TCL Strategic Development Manager: } \\
\text { Zhu Yiqun } \\
\text { TCL HR Dept.: Shi Liang } \\
\text { TCL CEO Office: Li Xuesong }\end{array}$ \\
\hline
\end{tabular}

